\title{
A note of appreciation from the IUSSI
}

This year Johan Billen stepped down as Editor of Insectes Sociaux after having served the longest term since the establishment of the journal. Johan dedicated 24 years of his life to our journal. He has played an immensely important role as Editor-in-Chief as will become clear when we have a look at the brief history of the journal, which Johan was so kind to send to me.

Insectes Sociaux was established in 1954. The journal did not have an Editor at the time, nor were manuscripts sent out for review. Instead a manuscript was sent to one of the members of the 'redaction committee' (translated from French: Comité de rédaction) who would pass it on to the Secretary. The Secretary would then decide on the relevance of figures and tables and check the corrected page proofs prior to publication. It took four volumes before it became compulsory that manuscripts were read by a reviewer. This meant that a manuscript would be read by one of the committee members, who could invite a 'reader'. Only in 1974 did the Secretary turn into Editor. From that point manuscripts were addressed to the Editor who invited two reviewers. Starting in 1983, the Editor was assisted by two Assistant Editors, and this changed to Associate Editors in 1996, a terminology still in use today.

When Johan took over in 1991 he was the first non-French Editor-in-Chief. Johan took over the reins at a time the journal also changed publisher, from Masson Publishers to Birkhaüser. Under Johan's watch, Insectes Sociaux published 1356 articles. In the 37 years before that 874 articles were published in the journal shared amongst four Secretaries/Editor-in-Chiefs. Although Associate Editors ably assisted Johan, he dealt with most if not all manuscripts on ants. Given that there are more ant species than any other social insect, this must mean his 'normal' editorial workload on top of being Editor-in-Chief was enormous. In addition, he would also have the final say after the Associate Editors had made their recommendations. I remember being rather unhappy about a rejection, and I wrote a lengthy email to Johan. He wrote a short, but nice, email back. Unfortunately, I no longer have the message, but the gist of it was that he understood my frustration, wasn't going to change his mind but hoped that getting it off my chest had been of help. It did help and I appreciated his response. Thank you Johan, for everything you have done for the IUSSI in general and the journal in particular. No doubt you quite enjoy having more time for other activities, but I strongly suspect you also miss Insectes Sociaux.

Our Secretary-General of the last eight years, Joan Herbers, also stepped down during the conference in Cairns this year. The IUSSI has seen many changes during her two terms. When Joan took over, the IUSSI more or less did not exist officially. The original paperwork, lodged in France, turned out to be unfindable. Thanks to Joan's organizational talent, she turned the IUSSI into a registered society with a constitution and by laws. Having a more formal organization became especially important when the IUSSI started to receive significant funds from Springer, who now publishes Insectes Sociaux. Joan and Johan did a tremendous job negotiating the contract with Springer that has allowed the IUSSI to start supporting its students to attend conferences. I felt honored when Joan asked me prior to the meeting in Cairns if I would be interested in taking over her role. She has also been a fantastic mentor to me the last few months as I am quickly learning the ropes. Thank you Joan, for your foresight and dedication to the IUSSI.

Madeleine Beekman Secretary-General, IUSSI 